\title{
Correction to: Economic uncertainty, precautionary motive and the augmented form of money demand function
}

\section{Pei-Tha Gan ${ }^{1}$ (D)}

Published online: 22 August 2019

(C) Japan Association for Evolutionary Economics 2019

\section{Correction to: Evolutionary and Institutional Economics Review https://doi.org/10.1007/s40844-019-00125-5}

In the original publication of the article, the Eq. 1 was published incorrectly. The correct version of Eq. 1 is as below,

$$
m_{t}=f\left(y_{t}, R_{t}\right) .
$$

The original article has been corrected.

Publisher's Note Springer Nature remains neutral with regard to jurisdictional claims in published maps and institutional affiliations.

The original article can be found online at https://doi.org/10.1007/s40844-019-00125-5.

Pei-Tha Gan

gan.pt@fpe.upsi.edu.my

1 Department of Economics, Faculty of Management and Economics, Universiti Pendidikan Sultan Idris (Sultan Idris Education University), 35900, Tanjong Malim, Perak, Malaysia 